\title{
Sightings of chestnut-flanked white-eye Zosterops erythropleurus: First report from Mizoram, India
}

\author{
Lalawmawia Sailo $^{1 *}$, Lawmsangzuala Chhangte ${ }^{2}$, Rochamliana Aineh, $^{3} \mathrm{H}$. Lalthanzara ${ }^{4}$ \\ ${ }^{\mathrm{I}}$ Department of Zoology, Mizoram University, Aizawl 796004, India \\ ${ }^{2}$ Khatla, ${ }^{3}$ Chanmari, Aizawl 7960oI, India \\ ${ }^{4}$ Department of Zoology, Pachhunga University College, Aizawl 7960oI, India
}

\begin{abstract}
In this paper we report the first confirmed sighting of chestnut-flanked white-eye Zosterops erythropleurus (Swinhoe, 1863) from Mizoram and first photographic report from India. chestnut-flanked white-eye belongs to the family Zosteropidae and is a resident of Cambodia, China, Hongkong, Korea, Democratic People's Republic of Korea, Laos, Myanmar, Russia, Thailand and Vietnam. In the Indian Sub-continent this is the only sighting report for this species and details of sightings and habitat are discussed.
\end{abstract}

Key words: Chestnut-flanked white eye, Mizoram, India, first report.
Received 15 March 2018 Accepted 21 April 2018

*For correspondence $\triangle$ : victorsailo87@gmail.com

Contact us $\square$ sciencevision@outlook.com

https://doi.org/10.33493/scivis.18.02.06
Chestnut-flanked white-eye Zosterops erythropleurus (Swinhoe, 1863) belongs to the family Zosteropidae. This diverse old world passerine family constitute a group of small, gregarious, arboreal birds having a wide range of distribution occupying tropical, sub-tropical and temperate Sub-Saharan Africa, southern and eastern Asia, Australasia and the tropical islands of the Indian Ocean, the western Pacific Ocean, and the Gulf of Guinea region. ${ }^{1}$ Although they occupy wide range of geographical area, morphological variation within the family is negligible, leading most members to be homogenous in appearance. The member of Zosteropidae exhibits remarkable uniformity in their morphology with greenish-olive above and pale grey below.

As their common name suggest, many species have a conspicuous white ring of tiny white feathers around the eyes. The size of this white eye-ring may differ between species, being highly conspicuous in some taxa and reduced or absent in other species. Some species have a bright yellow throat, white or cream coloured breast and several have buff flanks. ${ }^{1}$ All species of the family Zosteropidae are highly sociable and form large flocks that separate on the onset of the breedingseason. ${ }^{2}$ Species belonging to the family Zosteropidae are very vocal, but tend to have weak rather simple vocalizations that can be carried far. Zosteropidae are mainly insectivorous, but can be generalist eating nectar and fruits of various kinds.

Chestnut-flanked white-eye Z. erythropleurus is a resident of Cambodia, China, Hongkong, Korea, Democratic People's Republic of Korea, Laos, Myanmar, Russia, Thailand and Vietnam. ${ }^{3} \mathrm{Ot}-$ gonbayar et al. ${ }^{4}$ also reported the first sighting of Z. erythropleurus from Mongolia.

This report put forward and confirmed the presence of chestnut-flanked white-eye $\mathrm{Z}$. 


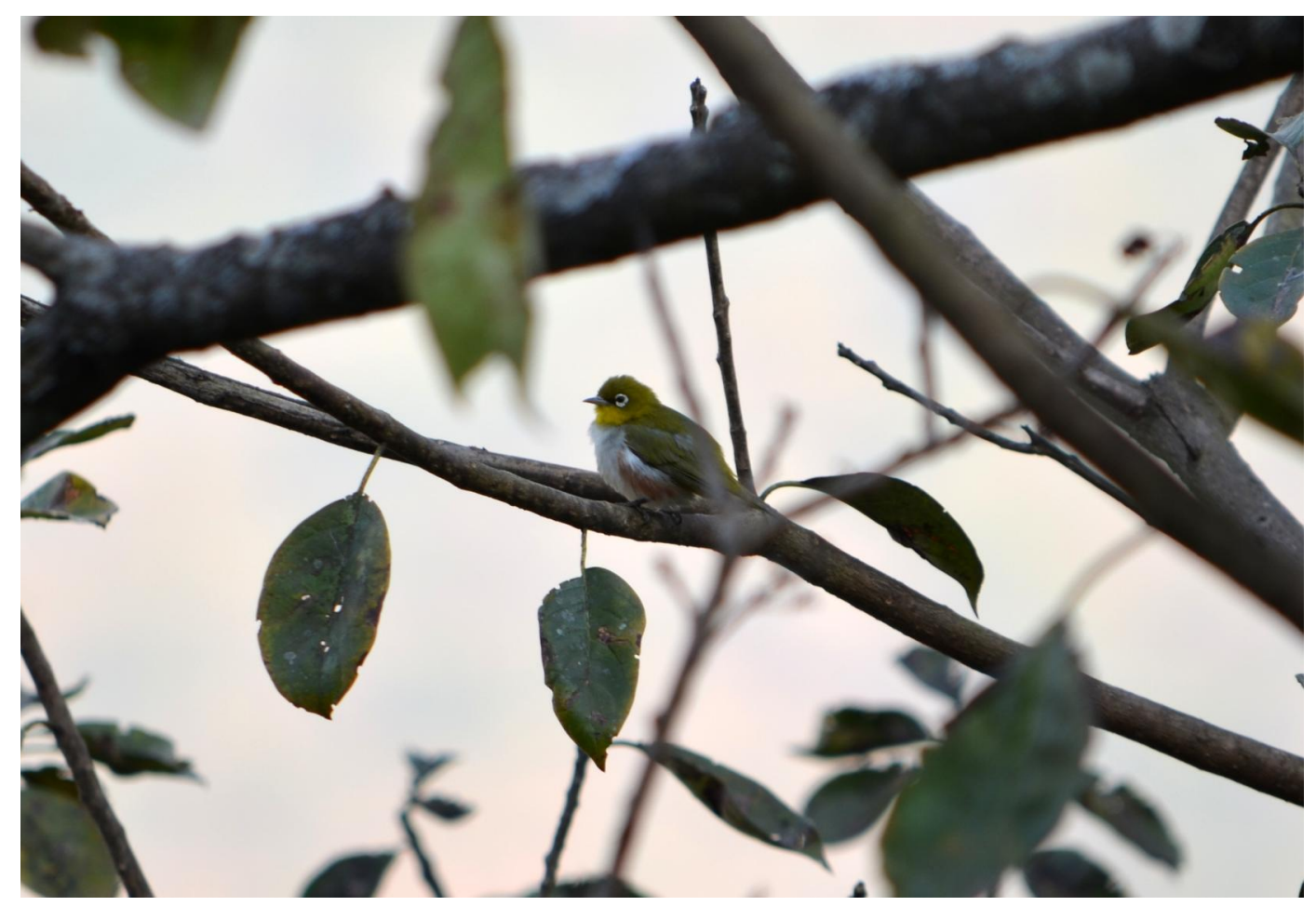

Figure 1 | Chestnut-flanked white eye Zosterops erythropleurus at Chaltlang, Aizawl.

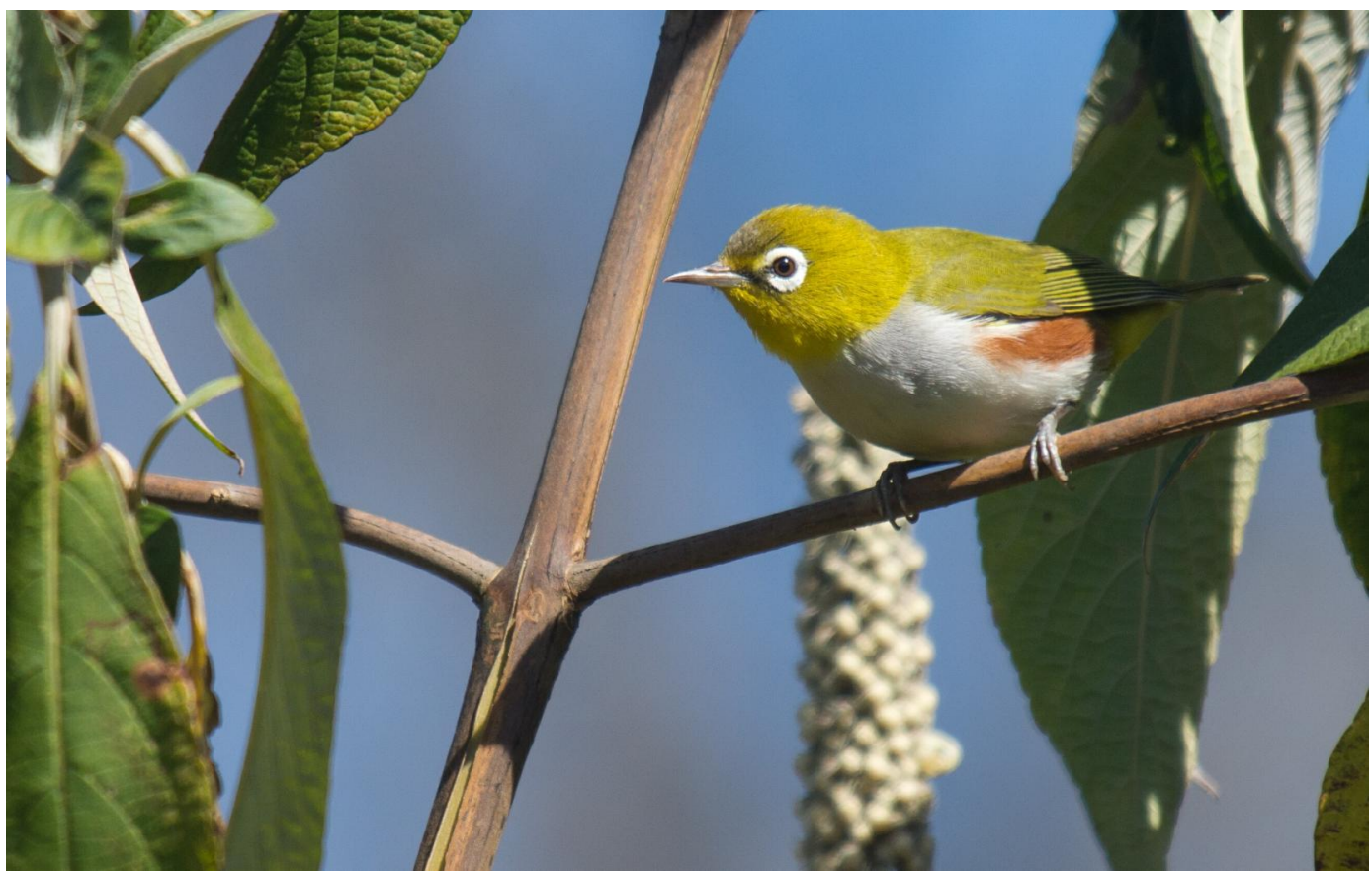

Figure 2 | Chestnut-flanked white eye Z. erythropleurus at Murlen National Park. 
erythropleurus in Mizoram and also the first photographic record of the species from the Indian sub-continent. The chestnut-flanked white-eye Z. erythropleurus was first sighted on the 6 February 2015,0856 hrs at a cliff top mixed vegetation of bamboo and small trees inside the area of Chaltlang locality of Aizawl city. The mix flock comprise of two Z. erythropleurus and six Z. palpebrosus. The encounter site is at an elevation of $1103.07 \mathrm{~m}$ above sea level with geo-co-ordinate $23^{\circ} 45^{\prime} 09.13^{\prime \prime} \mathrm{N} 92^{\circ} 43^{\prime} 20.40^{\prime \prime} \mathrm{E}$. The sighting was not supported by a high quality photograph which leaves the authors puzzled with the confirmation of the species. The photograph (Fig. 1) from the first sighting was inferior in quality due to the poor visibility with a thick fog. Two individuals of $Z$. erythropleurus were encountered among the flock of Oriental white-eye $Z$. palpebrosus, a commoner in the area.

The second and third author re-confirmed the species $Z$. erythropleurus with photograph from Murlen National Park located on the eastern side of Mizoram on the 16 and 18 January 2018. At around 1015 hrs in a bright morning, five $Z$. erythropleurus were seen among the flock of $40 \mathrm{Z}$. palpebrosus (Fig. 2) feeding on the nectar of Leucosceptrum canum (local name: kawi$h$ thuang) at $23^{\circ} 38^{\prime} 54.19^{\prime \prime} \mathrm{N} 93^{\circ} 17^{\prime} 28.80^{\prime \prime} \mathrm{E}$ at an elevation of $1640.73 \mathrm{~m}$.

The sightings from the state of Mizoram are only during the winter months which suggest that the birds are migrating from their home range and are readily forming a mixed flock with the closely related resident species of the family.

\section{Acknowledgement}

The authors convey their heartiest gratitude to the Range Officer and Staffs of Murlen National Park and to all those who extend their help during the study.

\section{References}

I. Van Balen, B. (2008). Family Zosteropidae (white eye). Pp. 402-485 in J. del Hoyo, A., Elliott, J., and Christie, D. A., eds, (2008). Handbook of the Birds of the World, I3, Barcelona: Lynx Editions.

2. Moreau, R.E. (1957) Variation in the western Zosteropidae (Aves). Bulletin of the British Museum, 4, 318-433.

3. BirdLife International. (2016). Zosterops erythropleurus. The IUCN Red List of Threatened Species 2016: e.T22714027A9439806o. http://dx.doi.org/I0.2305/

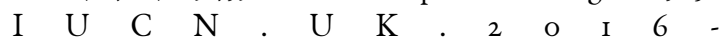
3.RLTS.T22714027A94398060.en. Downloaded on 25 January 2018.

4. Otgonbayar, B., Suuri, B., \& Reading, R.P. (2013). Chestnut-flanked White-eye Zosteropserythropleurus: First record for Mongolia. Birding Asia 20, III-II2. 